\title{
A Conceptual Framework For The Indirect Method Of Reporting Net Cash Flow From Operating Activities
}

Ting J. (TJ) Wang, Governors State University, USA

\begin{abstract}
This paper describes the fundamental concept of the reconciliation behind the indirect method of the statement of cash flows. A conceptual framework is presented to demonstrate how accrualand cash-basis accounting methods relate to each other and to illustrate the concept of reconciling these two accounting methods. The conceptual framework recognizes additional categories of effects defined in the Accounting Standards Codification 230-10-45-28 and International Accounting Standards 7.18 (Statement of Financial Accounting Standards No. 95) in regard to the indirect method, which makes the concept of reconciliation between the accrual-and cash-basis more thorough and complete. The paper provides an approach to teaching the concept of the reconciliation of accrual- and cash-based accounting methods.
\end{abstract}

Keywords: Accrual; Deferral; Reconciliation; Cash flow; Indirect method

\section{INTRODUCTION}

n college accounting programs, the statement of cash flows is usually scheduled for inclusion in the intermediate accounting courses even though the concept of cash flows; i.e., the direct method, may be suitable for business students in introductory financial accounting courses (O'Bryan, Berry, Troutman, and Quirin, 2000). The reason for this delay is that students must be acquainted with accrual-basis accounting in order to understand the indirect method of statement of cash flows (i.e., the reconciliation between accrual- and cash-basis accounting methods). When learning the indirect method, students are shown how to add (subtract) noncash expenses and make changes in certain balance sheet accounts to (from) net income, and they are provided with rationale for some of the additions (subtractions) account-by-account in relation to the reconciliation of net income and net cash flow, as seen in many intermediate accounting textbooks (Kieso, Weygandt, and Warfield, 2010). However, students often simply memorize the formula for these additions and subtractions instead of learning and understanding the concept of the reconciliation (O'Bryan, Berry, Troutman, and Quirin, 2000).

In the literature, in order to help students understand the indirect method, Rai (2003) shows how the change in cash account relates to changes in other accounts on the balance sheet using the basic accounting equation (or an algebraic approach) on financial statement data from two consecutive years. The changes in these balance sheet accounts are then classified into operating, investing, and financing categories, according to the sections reported on the statement of cash flows. This approach derives the additions and subtractions from the balance sheet accounts for each of the three sections of the statement of cash flows. It shows the absolute relationship between net operating cash flow and the additions to and subtractions from net income based on the derivations that arise from the accounting equation.

While Rai's method provides an analytical approach to derive the absolute relationship of net operating cash flow to the additions and subtractions of certain balance sheet accounts based on the accounting equation, his method does not provide the rationale for the additions and subtractions as related to the reconciliation of net income and net operating cash flow. That is, it does not explain the role of reconciliation; i.e., the fundamental relationship between the accrual- and cash-basis accounting methods. 
Accounting textbooks provide some examples and rationale for the effects of the additions and subtractions on net income, but they give only fragments of the concept of the reconciliation; i.e., they analyze the effect of just one addition or subtraction at a time on net income or on operating cash flow. For example, an increase in accounts receivable is one of the deductions because the increase (accrued revenues) was included in revenue (and net income) but not in cash. As a result, an increase in accounts receivable is subtracted from net income in the reconciliation to derive net operating cash flow. However, many students have difficulty understanding the concept and role of reconciliation. They have trouble understanding why any increase/decrease of balance sheet accounts should be subtracted from/added to net income to begin with; i.e., the concept of reconciliation. Furthermore, many students have a hard time understanding the effect of changes in inventories on net income.

Students' difficulties in understanding the concept of reconciliation may be contributed by incomplete definitions of the reconciliation/indirect method the standards and textbooks provide and by the fragmented singleaccount approach. For example, operating cash flows that do not affect income statement (i.e., cash transactions dealing with current assets or liabilities) are not specified in the definitions of the reconciliation. Under GAAP, in Accounting Standards Codification (ASC) 230-10-45-28 (SFAS 95), it defines the reconciliation/indirect method as follows: "that which requires adjusting net income of a business entity or change in net assets of an NFP to remove both of the following: 1) the effects of all deferrals of past operating cash receipts and payments, ...., and all accruals of expected future operating cash receipts and payments ... and 2) all items that are included in net income that do not affect net cash provided from ..." In addition, under IFRS, in International Accounting Standards (IAS) 7.18, it defines that "the indirect method adjusts accrued basis net profit or loss for the effects of non-cash transaction." It is clear from these definitions that non-cash transactions, such as depreciation or amortization expense, be added back to net income since they had a negative effect (the higher the depreciation, the lower the net income) on net income. Also, an increase in receivables reflects non-cash transaction or an item that is included in revenues and net income but does not affect net cash. As a result, an increase in receivables will be subtracted from net income because it had a positive effect (the higher the increase, the higher the non-cash amount contained in revenue, and the higher the non-cash amount in net income) on net income. However, the definitions do not mention what happens to a decrease in receivables, a decrease in payables, or any operating items that are not included in the income statement but do affect net cash (i.e., cash transaction that do not affect net income). Many students are confused with changes in inventories with respect to the reconciliation because there are other accounts (i.e., cost of goods sold, purchases, beginning accounts payable, and ending accounts payable) involved at the same time. The fragmented single-account approach is just not able to explain the effect of this change on net income at all.

This paper will focus on the operating section of the statement of cash flows; i.e., the reconciliation/indirect method. As a result, we will use operating income instead of net income in the paper. The reconciliation process requires two types of adjustments to the operating income: 1) to remove effects of accrual-basis operating transactions that have no effect on cash and 2) to include effects of cash-basis operating transactions that have no effect on operating income. The adjustments from the former item are clearly identified in ASC 230-10-45-28, IAS 7.18, and SFAS 95 par. 28, and covered in textbooks, but those from the latter are not specified (although shown in the example), making the definition and explanations incomplete.

To explain why and how the additions and subtractions relate to the reconciliation, one must first define accrual- and cash-basis accounting methods and demonstrate their relationship, then explain how the role of reconciliation works based on their relationship, and finally show how the additions and subtractions can be derived following the reconciliation of accrual- and cash-basis accounting methods.

To help students understand the reconciliation concept of the statement of cash flows, a conceptual framework is needed, which contains the basics of, and components in, both accrual- and cash-basis accounting; illustrates how the components of these two methods correspond to, and are reconciled with, each other; and shows the role of adjustments in the reconciliation.

This paper creates a conceptual framework to present the fundamental logic behind the indirect method for reconciling operating income to net operating cash flow. Further, the paper applies accounting terms related to ASC 23-10-45-28, lays out the components from both accrual- and cash-basis accounting, demonstrates the relationships among the components, derives the additions and subtractions, provides the rationale for the reconciliation in the indirect method, and describes the application of the framework. 


\section{A CONCEPTUAL FRAMEWORK}

\section{Terms and Their Relationships}

Before the conceptual framework can be presented, students must have a simple and basic understanding of a number of accounting terms, such as accrual, deferral, recognition and realization, their implications, and types of transactions (i.e., operating, financing and investing). Definitions and examples of these terms can be found in many financial accounting textbooks. For example, in accrual-basis accounting: revenues are recognized when they are earned, and expenses are recognized when they are incurred; revenues recognized before cash flow (or accrued revenues) will cause receivables to increase; and cash flow realized after being recognized will cause receivables to decrease.

To understand the conceptual framework for the indirect method of the statement of cash flows, the first step is to look at the operating transactions based on the sequence of occurrence between performance recognitions (i.e., revenues and expenses) and cash flow realizations (i.e., cash receipts and payments). We will focus on the indirect method of the statement of cash flows and target only the operating transactions. As a result, we will exclude financing and investing transactions from the conceptual framework in the paper. That is, we will use operating income instead of net income in the framework.

In general, all operating transactions involve exchanges of resources between the firm and other parties, internal or external - any exchanges that may or may not be completed by the end of a given reporting period. For example, a firm may deliver a part of or all goods and/or provide services to other parties prior to, at the time of, and/or after the receipts of cash payment. On the other hand, a firm may utilize resources and/or receive services provided by other parties prior to, at the time of, and/or after the payments of cash.

However, while only two transaction patterns have been defined by ASC 230-10-45-28 (SFAS 95) and included in accounting textbooks, we have identified six different transaction patterns in the conceptual framework. The six patterns are categorized based on the "sequence" of and "timing" of occurrence of a firm's performance and its related cash flows. There are two possible "sequences" of the firm's performance (i.e., recognitions of revenues or expenses) and its related cash flows; i.e., (1) performance occurs prior to cash flows and (2) cash flows occur prior to performance, and three possible "timings" of these occurrences; i.e., (1) current-future, (2) past-current and (3) current-current accounting periods. The six patterns (i.e., 2 × 3 ) are as follows: Pattern 1, when the firm delivers goods or provides services to (utilizes resources or receives services provided by) other parties during the current accounting period prior to the receipts (payments) of cash in the future accounting periods [Performance $\rightarrow$ Cash Flows \& Current-Future]; Pattern 2, when the firm receives cash from (pays cash to) other parties during the current accounting period for the goods delivered or services provided (resources utilized or services received) from past accounting periods [Performance $\rightarrow$ Cash Flows \& Past-Current]; Pattern 3, when the firm delivers goods or provides services to (utilizes resources or receives services provided by) other parties during the current accounting period but receives (makes) the payments of cash either at the time of delivery or by the end of the same current accounting period [Performance $\rightarrow$ Cash Flows \& Current-Current]; Pattern 4, when the firm receives cash from (pays cash to) other parties during the current accounting period for goods or services (resources or services) to be delivered (used) in the future accounting periods [Cash Flows $\rightarrow$ Performance \& Current-Future]; Pattern 5, when the firm delivers goods or provides services to (utilizes resources or services provided by) other parties during the current accounting period after receiving (making) the payments of cash from past accounting periods [Cash Flows $\rightarrow$ Performance \& Past-Current]; and Pattern 6, when the firm receives payments of cash from (pays to) other parties during the current accounting period but delivers goods or provides services (utilizes resources or receives services) either at the time of the payment or by the end of the same accounting period [Cash Flows $\rightarrow$ Performance \& Current-Current]. A transaction may follow one or a combination of these six transaction patterns.

Figure 1 illustrates these six transaction patterns and their terms which were created by the author using the same naming approach as in ASC 230-10-45-28 (SFAS 95). 


\section{Pattern}
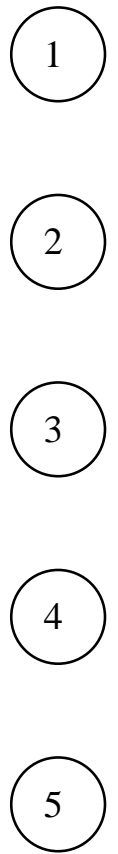

$\$$
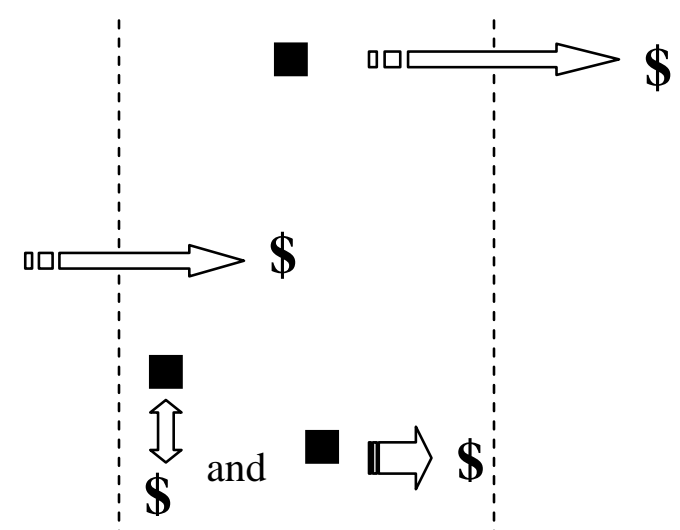

Accruals of current cash flows

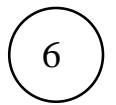

6
$\$$

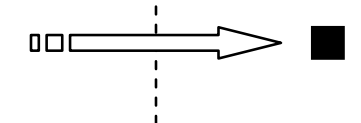

Cash flows of future deferrals

Deferrals of past cash flows (as defined in ASC 230-10-45-28)

Cash flows of current deferrals

Time (Accounting Period)
Accruals of expected future cash flows (as defined in ASC 230-10-45-28)

Cash flows of past accruals

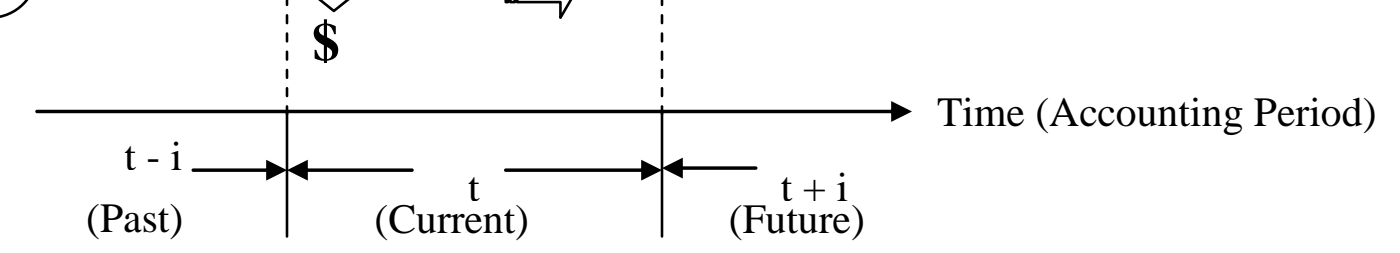

\section{LEGEND}

The firm delivers goods or provides services to (utilizes resources or receives services provided by) other parties

$\$$ The firm receives payments of cash from (pays cash to) other parties

t Current accounting period

$\mathrm{t}-\mathrm{i}$ Past accounting periods

$\mathrm{t}+\mathrm{i}$ Future accounting periods

$$
\mathrm{i}=1,2,3, \ldots, \mathrm{n}
$$


In ASC 230-10-45-28, the term "accruals of expected future operating cash receipts and payments" is consistent with transactions in Pattern 1 when the firm delivers goods or provides services to (utilizes resources or receives services provided by) other parties during the current accounting period prior to the receipts (payments) of cash in the future accounting periods. These transactions are accrued revenues and accrued expenses, for which we debit Receivables and credit Revenues for the accrued revenues, and debit Expenses and credit Payables for the accrued expenses in the recording of the transactions.

Another term defined in ASC 230-10-45-28 is "deferrals of past operating cash receipts and payments," which is consistent with transactions in Pattern 5, when the firm delivers goods or provides services to (utilizes resources or services provided by) other parties during the current accounting period after receiving (making) the payments of cash from past accounting periods. These transactions include debiting Deferred Liabilities (e.g., Unearned Revenues) and crediting Revenues, as well as debiting Expenses and crediting Deferred Assets (e.g., Prepayments).

As seen in ASC 230-10-45-28, there are two elements in the naming of terms; for example, accruals/deferrals (i.e., the sequence of the recognition of performance and the realization of its related cash flows), and past/expected future (i.e., the timing of operating cash receipts and payments). From here on, we will use the general term "cash flows" to mean "operating cash receipts and payments" since we limit the scope of the framework to the operating transactions only. ASC 230-10-45-28 uses "accruals" for the recognitions of performance that occur before realization of the related cash flow, and it uses "deferrals" for the recognitions of performance that occur after realization of the cash flow. The current accounting period is referred in this paper as the time period which the most current financial statements; i.e., the period in which the recognitions of revenues and expenses took place, cover. We use the same naming convention as in ASC 230-10-45-28 with the elements involved in the six patterns to create terms such as "cash flows of past accruals", "accruals of current cash flows", "cash flows of future deferrals", and "cash flows of current deferrals" for Patterns 2, 3, 4, and 6, respectively. Operating transactions in "cash flows of past accruals" (Pattern 2) are follow-up related transactions from "accruals of expected future cash flows" (Pattern 1), and transactions in "deferrals of past cash flows" (Pattern 5) are followup related transactions from "cash flows of future deferrals" (or Pattern 4). Although net effects on the accounts from transactions in "accruals of current cash flows" (Pattern 3) and "cash flows of current deferrals" (Pattern 6) are the same at the end of current accounting period, the actual sequence of occurrence in the transactions might be different. As mentioned before, an actual transaction may consist of multiple patterns of transactions classified above.

\section{Accrual- Versus Cash-Basis Accounting Methods}

After the terms of the components of both accounting methods are understood as delineated above, the next step is to examine the operating transactions, both accrual- and cash-basis, that have been recorded by the end of the current period, including all year-end adjustments, as depicted in Figure 2. Giving six patterns of operating transactions, there are four of them that would affect operating income and four of them net operating cash flow. The patterns of transactions that would affect operating income are "accruals of expected future cash flows" (Pattern 1), "accruals of current cash flows" (Pattern 3), "deferrals of past cash flows" (Pattern 5), and "cash flows of current deferrals" (Pattern 6) because the firm has performed (i.e., delivered goods and/or provided services or utilized resources and/or received goods/services) during the current accounting period. On the other hand, the patterns of transactions that would affect net operating cash flow include "cash flows of past accruals" (Pattern 2), "accruals of current cash flows" (Pattern 3), "cash flows of future deferrals" (Pattern 4), and "cash flows of current deferrals" (Pattern 6) because the firm has received/used cash during the current accounting period.

Transactions in "accruals of current cash flows" (Pattern 3) and "cash flows of current deferrals" (Pattern 6) are included under both accrual- and cash-basis accounting methods because, in these transactions, recognitions (revenues and expenses affecting operating net income) and realizations (cash receipts and payments affecting net operating cash) have occurred at the same time or at different times by the end of the current accounting period. 
Figure 2: Reconciliation of Accrual- and Cash-basis Accounting

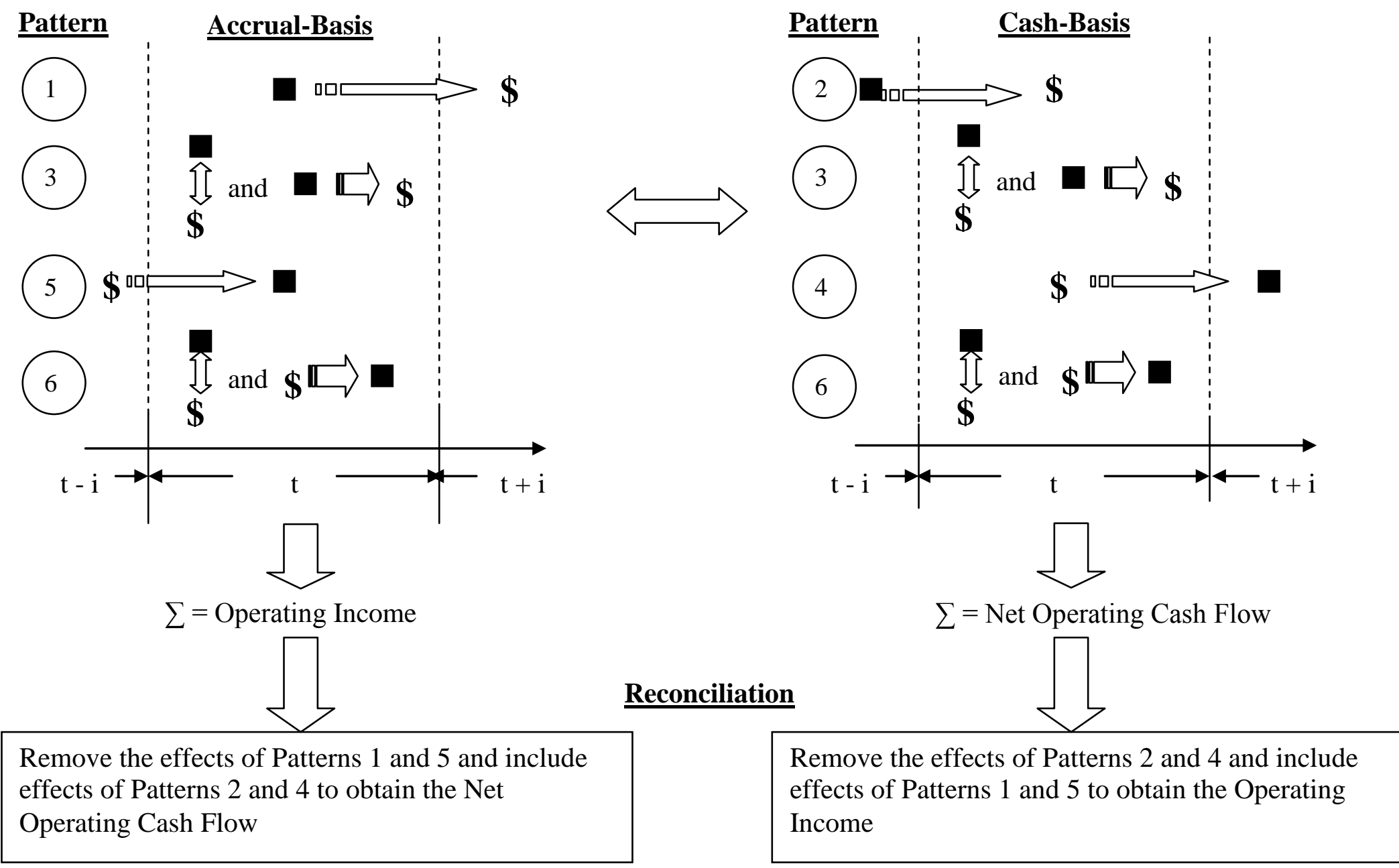


Another way of looking at these two accounting bases is to note that operating transactions which are associated with performance in the current period under the "accrual-basis" are all reflected in the operating income in the current accounting period with their associated cash flows occurring in the past, current or future accounting periods. On the other hand, operating transactions which are associated with cash flows in the current period under the "cash-basis" are all accounted in the net operating cash flow with their related performance recognized in the past, current or future accounting periods (i.e., recognitions that occurred in the past, are occurring in the current, or are expected to occur in the future accounting periods). Operating transactions in Patterns 3 and 6 are all reflected in the operating income and net operating cash flow in the current accounting period. As a result, these transaction patterns affect both "accrual-basis" and "cash-basis" accounting concurrently, making them irrelevant in the reconciliation of these two methods.

On the other hand, operating transactions in Patterns 1 and 5 are reflected in the operating income but not in the net operating cash flow because their related cash flows are expected to be realized in the future (Pattern 1) or have been realized in the past (Pattern 5) periods. Operating transactions in Patterns 2 and 4 are reflected in the net operating cash flow but not in the operating income because their related recognitions of revenues and expenses have been occurred in the past (Pattern 2) or are expected to be occurred in the future (Pattern 4) periods.

\section{The Concept of Reconciliation}

All operating transactions under "accrual-basis"--some of which are related to revenues and others to expenses--are included in the calculations of the current income statement. Thus, the end result under the "accrualbasis" method is the operating income reported (i.e., revenues - expenses) on the income statement, which discloses the performance outcome of the current accounting period.

The end result from operating transactions under the "cash-basis" is the change in cash/net operating cash flow (i.e., cash inflows - cash outflows) from that period, which is disclosed on the statement of cash flows. Therefore, to reconcile operating income (accrual-basis) to net operating cash flow (cash-basis) is to show how to obtain the result of "cash-basis" transactions from the result of "accrual-basis" transactions using the similarity and differences of the types of transactions (i.e., components) identified under both "accrual-basis" and "cash-basis" accounting methods.

To carry out this reconciliation, we simply exclude types of transactions (i.e., components) that are under "accrual-basis" but not under "cash-basis" and then include types of transactions that are under "cash-basis" but not under "accrual-basis". That is, we exclude "accruals of expected future cash flows" (Pattern 1) and "deferrals of past cash flows" (Pattern 5) from "accrual-basis" transactions (or from the end result--operating income), and then include "cash flows of past accruals" (Pattern 2) and "cash flows of future deferrals" (Pattern 4) to obtain the result of "cash-basis" transactions; i.e., net operating cash flow.

In other words, operating transactions in Patterns 1 and 5 affected operating income but did not affect cash, and operating transactions in Patterns 2 and 4 affected cash but did not affect operating income. Thus, to reconcile operating income to net operating cash flow is to remove effects of transactions found in Patterns 1 and 5 on operating income and include effects of transactions found in Patterns 2 and 4 to obtain net operating cash flow.

\section{VALIDATION OF THE FRAMEWORK}

In this section, we will demonstrate how the logic of the reconciliation outlined above can actually be applied by excluding the effects of transactions in Patterns 1 and 5 from operating income and including the effects of transactions in Patterns 2 and 4 to operating income using major and commonly observed categories from the income statement, such as revenues, cost of goods sold, depreciation, and other expenses. In other words, we will illustrate how to obtain the additions and subtractions seen in the textbooks directly from the conceptual framework outlined above. 
Figure 3: Effects of Accrual- and Cash-basis Accounting on Balance Sheet Accounts

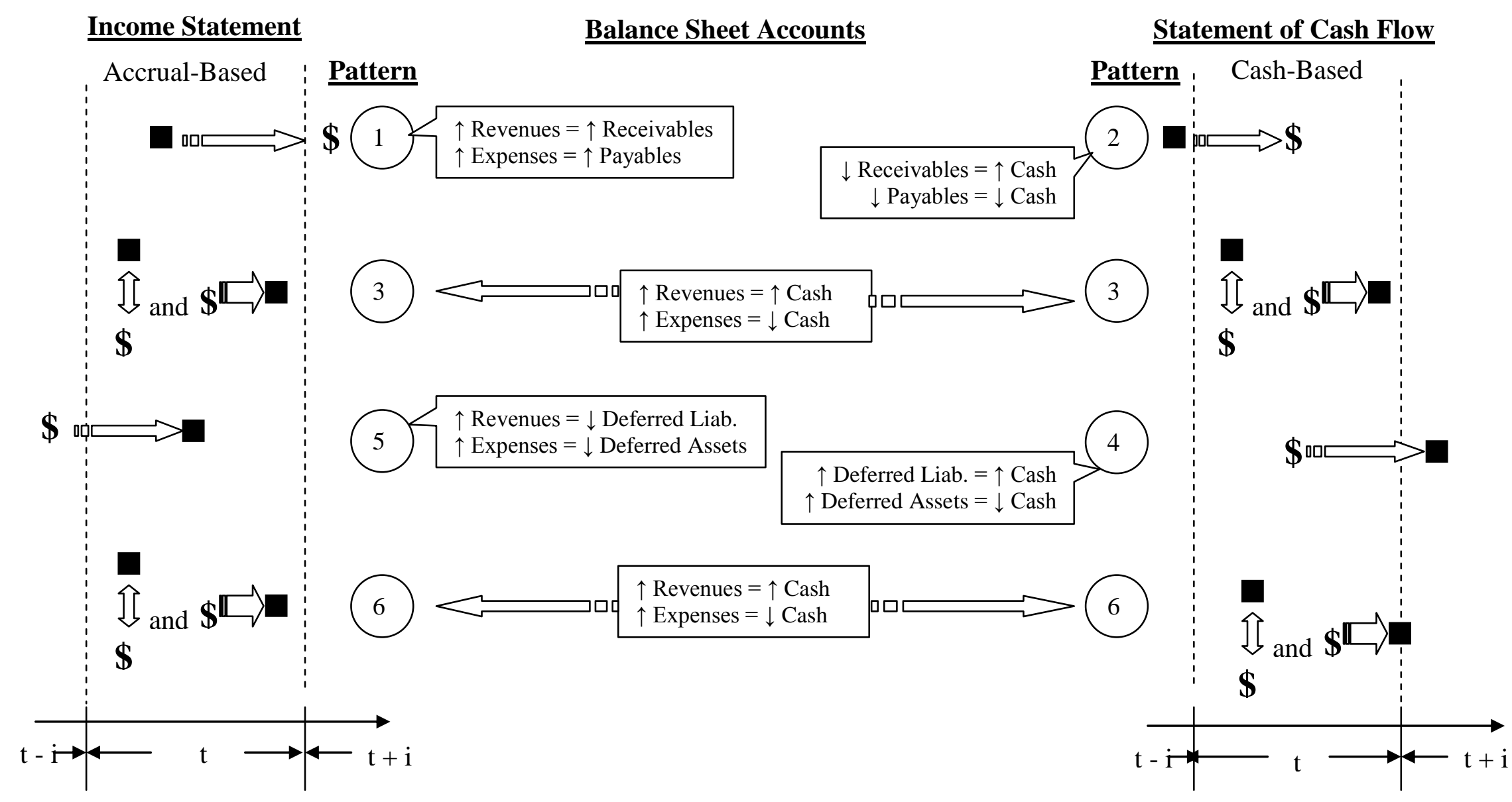


Table I: Rationales of the Additions and Subtractions of Balance Sheet Accounts in the Reconciliation

\begin{tabular}{|c|c|c|c|c|c|}
\hline \multirow[b]{2}{*}{$\begin{array}{c}\text { Column A } \\
\text { Income Statement } \\
\text { Items }\end{array}$} & \multicolumn{2}{|c|}{ Accrual-Basis (To be Excluded) } & \multicolumn{2}{|c|}{ Cash-Basis (To be Included) } & \multirow[b]{2}{*}{$\begin{array}{c}\text { Column F } \\
\text { Adjustments to Net Income due to } \\
\text { Columns B E }\end{array}$} \\
\hline & $\begin{array}{c}\text { Column B } \\
\text { Pattern 1: Accruals of } \\
\text { Exp. Future CF }\end{array}$ & $\begin{array}{c}\text { Column C } \\
\text { Pattern 5: Deferrals of Past } \\
\text { CF }\end{array}$ & $\begin{array}{c}\text { Column D } \\
\text { Pattern 2: CF of Past } \\
\text { Accruals }\end{array}$ & $\begin{array}{c}\text { Column E } \\
\text { Pattern 4: CF of Future } \\
\text { Deferrals }\end{array}$ & \\
\hline Revenues & $\begin{array}{l}\text { Credit sales included } \\
\text { and } A / R \text { increased. } \\
\text { ( } \uparrow \mathbf{A} / \mathbf{R})\end{array}$ & $\begin{array}{c}\text { Advanced sales recognized } \\
\text { and Unearned Revenue } \\
\text { decreased. } \\
\text { ( } \downarrow \text { Unearned Revenue) }\end{array}$ & $\begin{array}{l}\text { Sales collection received } \\
\text { and A/R decreased. } \\
(\downarrow \mathbf{A} / \mathbf{R})\end{array}$ & $\begin{array}{c}\text { Advanced sales included } \\
\text { and Unearned Revenue } \\
\text { increased. } \\
\text { ( } \uparrow \text { Unearned Revenue) }\end{array}$ & $\begin{array}{c}-\Delta \mathbf{A} / \mathbf{R} \\
+\Delta \text { Unearned Revenue }\end{array}$ \\
\hline - COGS & $\begin{array}{l}\text { Credit purchases } \\
\text { included and } \mathrm{A} / \mathrm{P} \\
\text { increased. } \\
(\uparrow \mathbf{A} / \mathbf{P}) \\
\end{array}$ & & $\begin{array}{l}\text { Credit purchases paid and } \\
\text { A/P decreased. } \\
(\downarrow \mathbf{A} / \mathbf{P})\end{array}$ & & $\begin{array}{c}+\Delta \mathbf{A} / \mathbf{P} \\
-\Delta \text { Inventories }\end{array}$ \\
\hline - Depreciation & & $\begin{array}{c}\text { Depreciation allocated and } \\
\text { Depreciation Expense } \\
\text { increased. } \\
\text { ( } \uparrow \text { Depreciation Exp) }\end{array}$ & & & + Depreciation \\
\hline - Expenses & $\begin{array}{l}\text { Expenses accrued and } \\
\text { Payables increased. } \\
\text { ( } \uparrow \text { Payables) }\end{array}$ & $\begin{array}{l}\text { Prepaid expenses recognized } \\
\text { and Prepayment decreased. } \\
\text { ( } \downarrow \text { Prepayments) }\end{array}$ & $\begin{array}{c}\text { Payment of accrued } \\
\text { expenses and Payables } \\
\text { decreased. } \\
\text { ( } \downarrow \text { Payables) } \\
\end{array}$ & $\begin{array}{l}\text { Prepaid expenses and } \\
\text { Prepayment increased. } \\
\text { ( } \uparrow \text { Prepayments) }\end{array}$ & $\begin{array}{c}+\Delta \text { Payables } \\
-\Delta \text { Prepayments }\end{array}$ \\
\hline$=$ Net Income & & & & & \\
\hline
\end{tabular}

COGS = Cost of Goods Sold, (i.e., Beginning Inventories + Net Purchases - Ending Inventories); Exp = Expected; CF = Cash Flows; A/R = Accounts Receivable; A/P = Accounts Payable.

Result:

Net Operating CF $\quad=$ Net Income excludes effects from Columns B and C and includes effects from Columns D and E

$=$ Net Income $-\Delta \mathrm{A} / \mathrm{R}+\Delta$ Unearned Revenue $+\Delta \mathrm{A} / \mathrm{P}-\Delta$ Inventories + Depreciation $+\Delta$ Payables $-\Delta$ Prepayments 
Operating transactions in Patterns 1 and 5 have already been accounted in operating income for the current period. These two patterns of transactions might cause operating income to increase or decrease depending on the types of transactions. For example, recognized revenues (revenues were credited) from Patterns 1 and 5 would cause operating income to increase while recognized expenses (expenses were debited) would cause operating income to decrease. To exclude Patterns 1 and 5 is equivalent to removing their effects (i.e., increases or decreases) from the end result of operating income, which is also consistent with the language used in the ASC 230-10-45-28. Thus, we will add their effects back to operating income if they were subtracted to derive operating income (i.e., caused operating income to decrease--recognized expenses), and subtract the effects from operating income if they were added to derive operating income (i.e., caused operating income to increase--recognized revenues).

When transactions in Patterns 1 and 5 have effects on operating income, they must have effects on the balance sheet accounts as seen in Figure 3, according to the double-entry bookkeeping system. For example, operating transactions in Pattern 1; i.e., accrued revenues (expenses) have increased (decreased) operating income, so they must have also increased receivables (payables). Transactions in Pattern 5; i.e., deferrals of past cash flows (receipts and payments), have increased (decreased) operating income, so they must have also decreased deferred liabilities (assets). Furthermore, when transactions in Patterns 2 and 4 have effects on cash, they must have effects on the balance sheet accounts. For example, transactions in Pattern 2; i.e., cash flows of past accruals, have increased (decreased) cash, so they must have also decreased receivables (payables). Transactions in Pattern 4; i.e., cash flows of future deferrals, have increased (decreased) cash, so they must have also increased deferred liabilities (assets). As a result, these increases and decreases (changes) in balance sheet accounts can be used to reflect (i.e., proxy for) the effects on operating income and cash from transactions addressed above and used in the adjustments in the reconciliation of the two accounting bases.

To demonstrate how the additions and subtractions can actually be derived from the conceptual framework, let's first decompose the major income statement categories into types of transactions according to the following: Pattern 1, "accruals of expected future cash flow"; Pattern 2, "cash flows of past accruals"; Pattern 4, "cash flows of future deferrals"; and Pattern 5, "deferrals of past cash flows".

Next, we shall identify the effects of these patterns on operating income and net operating cash flow and, subsequently, make appropriate adjustments in order to remove or include their effects. In Table I, the major income statement categories are listed in Column A. "Accruals of expected future cash flows" are shown in Column B (Pattern 1). Column C shows "deferrals of past cash flows" (Pattern 5). Columns D and E list "cash flows of past accruals" (Pattern 2) and "cash flows of future deferrals" (Pattern 4), respectively. Column F reports the adjustments that will be needed to remove and include the effects that Columns B to E have had on operating income. These adjustments must be consistent with the additions and subtractions seen in the textbooks.

The following describes how to obtain the aforementioned effects from the income statement items:

Revenues - COGS - Depreciation - Expenses $=$ Net Income

\section{Revenues}

Revenues on the income statement may consist of cash sales (i.e., "accruals of current cash flows" in Pattern 3 and "cash flows of current deferrals" in Pattern 6), credit sales ("accruals of expected future cash flows" in Pattern 1), and deferred sales ("deferrals of past cash flows" in Pattern 5). In this case, cash sales are considered as sales transactions recognized, in whole or in part, during the period in which they are also realized. Credit sales include sales transactions recognized, in whole or in part, during the period but not yet realized by the end of the period. Deferred sales are sales transactions realized, in whole or in part, during the period but not yet recognized by the end of the period.

Credit sales that were recognized but not realized by the end of the period (i.e., "accruals of expected future cash flows" in Pattern 1, and Table I, Column B) have caused Accounts Receivable (A/R), as well as Revenues and operating income, to increase - and the effect of this increase in $A / R$ (also in operating income) must be removed (i.e., be subtracted) from operating income in the reconciliation according to the conceptual framework. On the other hand, credit sales that were recognized in the past period and realized by the end of the current period (i.e., "cash 
flows of past accruals" in Pattern 2, and Table I, Column D) have caused A/R to decrease and cash to increase-and the effect of the decrease in $\mathrm{A} / \mathrm{R}$ must be included (i.e., added) to operating income in the reconciliation. Since an increase in $A / R$ must be subtracted from operating income and a decrease in $A / R$ must be added to operating income, change in the $\mathrm{A} / \mathrm{R}$ (i.e., $\mathrm{A} / \mathrm{R}_{\mathrm{t}}-\mathrm{A} / \mathrm{R}_{\mathrm{t}-1}$ ) is one of the subtractions from operating income in the reconciliation/indirect method of the statement of cash flows (Table I, Column F), assuming the A/R account is used for operating transactions only.

Deferred sales that were realized in the past and recognized currently (i.e., "deferrals of past cash flows" in Pattern 5, and Table I, Column C) have caused deferred liabilities (e.g., Unearned Revenue) to decrease and Revenues (and operating income) to increase - and the effect of this decrease in deferred liabilities (or increase in Revenues and operating income) must be excluded (i.e., be subtracted) from operating income in the reconciliation. However, deferred sales that are currently realized but expected to be recognized in the future (i.e., "cash flows of future deferrals" in Pattern 4, and Table I, Column E) have caused deferred liabilities and cash to increase - and the effect (i.e., the increase in deferred liabilities) must be included (i.e., be added) to operating income in the reconciliation. As a result, change in deferred liabilities is one of the additions to operating income in the reconciliation/indirect method of the statement of cash flows (Table I, Column F).

\section{Cost of Goods Sold}

The item, Cost Of Goods Sold (COGS), in the income statement can be derived by taking the beginning inventories $\left(\operatorname{Inv}_{t-1}\right)$, adding net purchases, and then subtracting the ending inventories $\left(\operatorname{Inv}_{t}\right)$ (i.e., $\operatorname{COGS}=\operatorname{Inv}_{t-1}+$ Net Purchases $\left.-\mathrm{Inv}_{\mathrm{t}}\right)$. COGS is subtracted from Revenues in order to arrive at operating income in the income statement (Revenues - COGS - Depreciation - Expenses = Operating Income). Since COGS is equal to Net Purchases minus Change in Inventories, we will deal with the effects of these two items instead of COGS on operating income.

Net Purchases may result from cash purchases; i.e., transactions in Patterns 3 and 6 , and/or credit purchases; i.e., transactions in "accruals of expected future cash flows" in Pattern 1 and Table I, Column B. Credit purchases have caused A/P to increase, and they also caused COGS (by holding inventories constant) to increase and operating income to decrease. To remove the effect of credit purchases, the increase in A/P (proxy for the Credit Purchases) must be excluded from (i.e., added to) operating income in the reconciliation. Likewise, credit purchases previously recognized and realized by the end of the current period; i.e., transactions in "cash flows of past accruals" in Pattern 2 and Table I, Column D, have caused cash to increase and A/P to decrease-and this decrease in A/P (proxy for the Credit Purchases that were paid) must be excluded (i.e., subtracted) from operating income. As a result, change in $\mathrm{A} / \mathrm{P}$ is one of the additions to the operating income in the reconciliation according to the conceptual framework (Table I, Column F).

To remove the effect of Change in Inventories on operating income, we must exclude or subtract the Change in Inventories from operating income since the "negative" Change in Inventories (via COGS) has been subtracted from Revenues to derive operating income (e.g., by replacing the COGS in the equation: Revenues - (Net Purchases - Change in Inventories) - Depreciation - Expense = Operating Income). Consequently, Change in Inventories is one of the subtractions from the operating income in the reconciliation (Table I, Column F).

\section{Depreciation}

Depreciation expenses are non-cash or accrued items that are estimated and recognized in each future period during the estimated life of the assets regardless of when the payments of the assets were made. It is similar to transactions in "deferrals of past cash flows" in Pattern 5 (as well as Patterns 1, 3, and/or 6), and is subtracted to derive operating income. Therefore, to remove the effect of Depreciation on operating income, we add it back to operating income. As a result, depreciation expense is one of the additions to operating income (Table I, Column F). 


\section{Expenses}

Other Expenses will follow the same logic explained above in COGS and Unearned Revenue. Recognized expenses have caused payables to increase (i.e., "accruals of expected future cash flows" in Pattern 1, and Table I, Column B) and realized expenses have caused payables to decrease (i.e., "cash flows of past accruals" in Pattern 2, and Table I, Column D). Since Expenses are subtracted to derive operating income, the Change in Payables must be added back to operating income, and the Change in Prepayments must be subtracted from operating income. As a result, Change in Payables is one of the additions to operating income, and Change in Prepayments is one of the subtractions from operating income (Table I, Column F).

In summary, when reconciling operating income to net operating cash flow, we remove effects of non-cash recognitions (i.e., transactions in Patterns 1 and 5) from operating income and include effects of non-recognized cash flows (i.e., transactions in Patterns 2 and 4). These non-cash recognitions that must be removed and nonrecognized cash flows that must be included have the same effects not only on operating income and the cash account, respectively, but also on accounts in the balance sheet (as seen in Figure 3). The net effects on the accounts displayed in Table 1, Column F are identical to the additions to (e.g., change in Unearned Revenue, change in A/P, Depreciation, and change in Payables) and subtractions from (e.g., change in A/R, change in Inventory, and change in Prepayments) operating income seen in the textbooks.

\section{CONCLUSIONS}

The conceptual framework in this paper demonstrates the fundamental concept of reconciliation behind the indirect method of the statement of cash flows. It provides a framework to enhance students' understanding of the rationale of the reconciliation. The framework applies the terms of the components defined in the ASC 230-10-4528 regarding the indirect method and recognizes additional components by laying out all possible patterns of transactions based on the sequence of occurrence between the timing of recognitions and the timing of realizations. The framework demonstrates how accrual- and cash-basis accounting methods relate to each other and how the two methods are reconciled using newly-identified components of transactions in the reconciliation.

Based on the framework, the reconciliation follows a process of first removing the effects of accrual-basis operating transactions that have no effect on cash; i.e., transactions in Patterns 1 and 5, and then including the effects of cash-basis operating transactions that have no effect on operating income; i.e., transactions in Patterns 2 and 4. The first type of effects - ones that must be removed - is specified in ASC 230-10-45-28 as "accruals of expected future cash receipts and cash payments" (Pattern 1 transactions in the framework), and "deferrals of past cash receipts and cash payments" (Pattern 5 transactions in the framework). In textbooks, these effects are also referred as "items that affected reported net income but did not affect cash" or "non-cash revenues and non-cash expenses" (Kieso, Weygandt, and Warfield). However, the second type of effects - ones that must be included - is not defined in the ASC 230-10-45-28, IAS 7.18 or in textbooks. Thus, the author's conceptual framework provides more thorough and complete components of transactions that will enhance students' understanding of the indirect method of reconciliation between accrual- and cash-basis accounting.

The framework also illustrates more thoroughly the rationale of how additions and subtractions are derived with respect to the reconciliation. Students can see from framework that additions and subtractions are the net results on proxy accounts representing the effects which need to be removed and included in the reconciliation of accrualand cash-basis accounting methods.

\section{AUTHOR INFORMATION}

Dr. TJ Wang is an associate professor at Governors State University. He has written a few papers related to relational database and won the Best Paper awards in the AIS Educator Annual Conference in 2002, 2004 and 2005. He has published some of the papers in the American Journal of Business Education, Journal of College Teaching and Learning, and Review of Business Information Systems. He has taught at Robert Morris University, University of Wisconsin-Milwaukee, Bellevue Community College, Rutgers University and New Jersey Institute of Technology. 


\section{REFERENCES}

1. Kieso, D. E., Weygandt, J. J., and Warfield, T. D. 2010. Intermediate accounting. $13^{\text {th }}$ ed. NY: John Wiley \& Sons.

2. O'Bryan, D., Berry, K. T., Troutman, C., and Quirin, J. J. 2000. Using accounting equation analysis to teach the statement of cash flows in the first financial accounting course. Journal of Accounting Education 18(2): 147-155.

3. Rai, A. 2003. Reconciliation of net income to cash flow from operations: an accounting equation approach. Journal of Accounting Education 21(1): 17-24. 
NOTES 